\title{
Quality Control of Waterproof and Drainage Construction for Planting Roof of Underground Garage Based on PDCA - Take A Project in Q City for Example
}

\author{
Si Chen ${ }^{1, *}$, Ming Liu ${ }^{1}$, and Tingting $\operatorname{Sun}^{1}$ \\ ${ }^{1}$ Qingdao University of Technology, China
}

\begin{abstract}
The roof of the underground garage of project A in Q city has been designed with waterproofing and drainage system of the planted roof. In the process of construction, there are some quality problems. Through the use of PDCA quality management cycle method, the quality problems are investigated and analyzed. And the corresponding plans, implementation of countermeasures, consolidation measures are made, so that the quality problems can be finally resolved to achieve the desired goal.
\end{abstract}

\section{Introduction}

As one of the 10 new technologies in the construction industry of the 2017 edition of the Ministry of Housing and Urban-Rural Construction, the planting roof is based on the top plane of the underground garage and has the functions of waterproof, drainage, water storage, green space and heat insulation. It can improve the urban ecological environment, alleviate the heat island effect, save energy and reduce emissions, and beautify the landscape. However, because of the complex roof system of underground garage roof planting, there are many construction procedures of waterproof and drainage. Whether from the requirements of technical specifications or design requirements, the construction is more difficult. Underground garage roof waterproofing belongs to the first-class waterproof, no water seepage, no wet stains on the structure surface. The design generally adopts structural waterproofing, membrane waterproofing, and combined waterproofing of seepage and drainage. They are all hidden projects. In the event of leakage, it is not appropriate to look for the causes of leakage. At the same time, the causes of leakage are not only related to the performance of building waterproofing, but also related to the upper layer of soil cover, pouring mode, climate and other conditions ${ }^{[1-3]}$.

\section{Investigation and analysis of $A$ project's quality in $Q$ city}

\subsection{Engineering profile}

Q city has a temperate oceanic climate. Project A includes multi-storey houses, townhouses, ancillary facilities and underground garages. The total construction area of the project is 26057.03 square meters. The underground garage building area is 5448.18 square meters, and the roof of the underground garage adopts planted roof.

Both the common waterproof layer and the root resistant waterproof layer of the roof are made of self-adhesive polymer waterproof membrane, combined with rigid waterproof structure board, to form a rigid and flexible composite waterproof system. The drainage system adopts HDPE drainage (storage) plate + side ditch + roof drain combination type active drainage. At the same time, the project fully considered the types of trees planted, load size and other factors. In order to protect the drainage system and prevent the uneven settlement of the planting soil, the cast-in-place reinforced concrete slab is laid under the tree planting soil layer with high load and strong puncture, so as to improve the puncture resistance (See Fig. 1). 


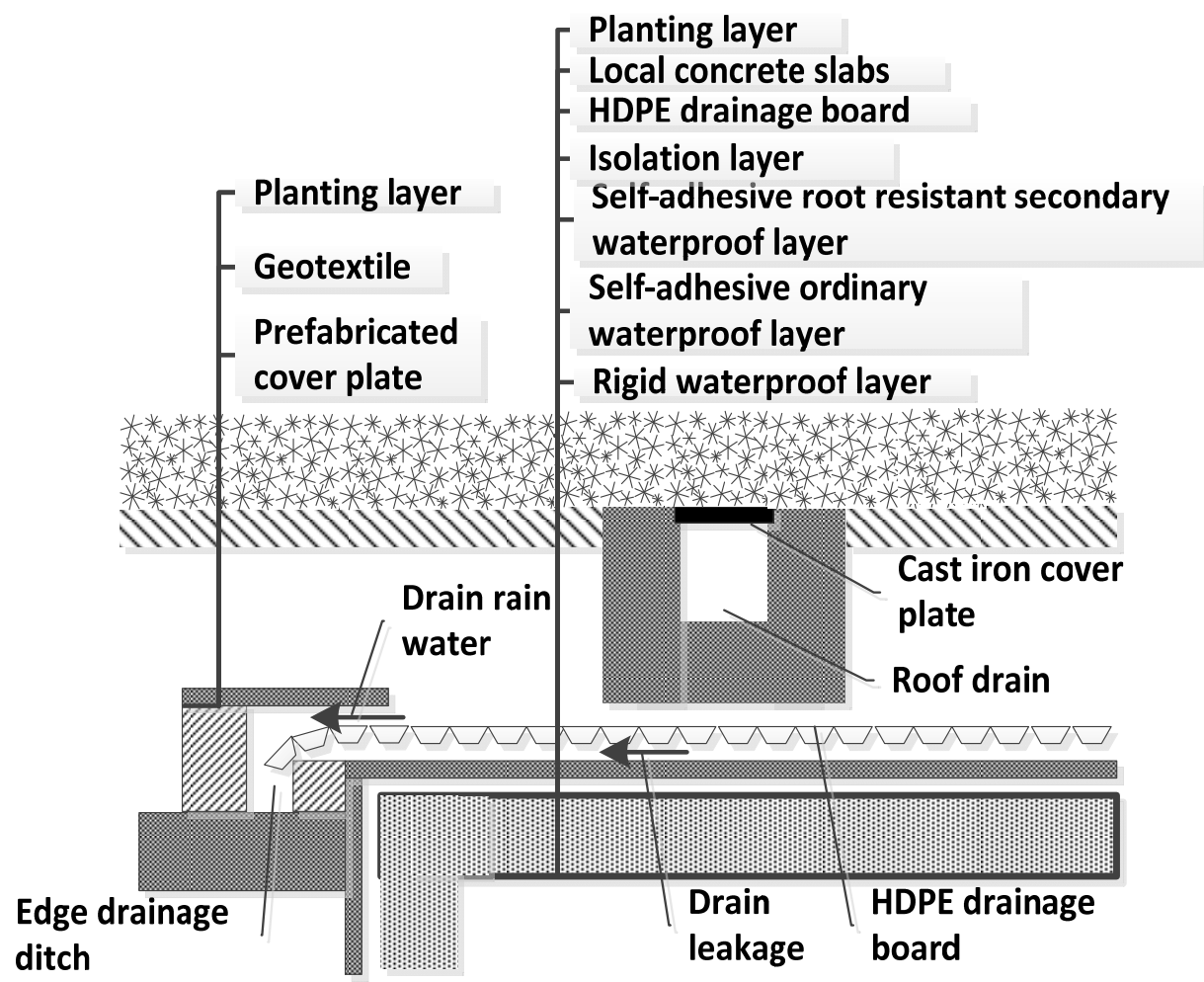

Fig. 1. Waterproofing and drainage system for planting roo

\subsection{Quality defects}

Through the field inspection of the 5 locations which are prone to disqualification, 60 measured points are taken separately, and the frequency of nonconformity is counted (see Table 1). It is found that wet stains usually occur after sudden downpour, and the long duration of rainy season is easy to appear wet stains. The expert analysis is mainly due to the lack of seepage or blockage.

Table 1. Quality defect statistics

\begin{tabular}{|c|c|c|c|c|c|c|c|}
\hline & Project & Numbers & Qualified & $\begin{array}{c}\text { Qualified } \\
\text { rate }\end{array}$ & unqualified & $\begin{array}{c}\text { unqualified } \\
\text { rate }\end{array}$ & $\begin{array}{l}\text { Cumulative } \\
\text { frequency }\end{array}$ \\
\hline 1 & $\begin{array}{l}\text { Slope and direction } \\
\text { of HDPE plates }\end{array}$ & 60 & 42 & \multirow{6}{*}{$86.7 \%$} & 18 & $45 \%$ & $45 \%$ \\
\hline 2 & HDPE plates smoothness & 60 & 45 & & 12 & $30 \%$ & $75 \%$ \\
\hline 3 & Geotextile suture firm & 60 & 53 & & 7 & $17.5 \%$ & $92.5 \%$ \\
\hline 4 & Geotextile smoothness & 60 & 58 & & 2 & $5 \%$ & $97.5 \%$ \\
\hline \multirow[t]{2}{*}{5} & HDPE lap & 60 & 59 & & 1 & $2.5 \%$ & $100 \%$ \\
\hline & Total & 300 & 260 & & 40 & $100 \%$ & \\
\hline
\end{tabular}

measurement. Through table 1, two main factors

\subsection{Causes analysis}

Through collecting the opinions of relevant personnel on the construction site extensively and adopting the "brainstorming method", this paper starts from six aspects: person, material, machine, method, ring and affecting the quality of drainage construction of planting roof are analyzed: slope and direction of HDPE plate and smoothness of HDPE plate, and nine end factors are obtained (See Fig. 2). 


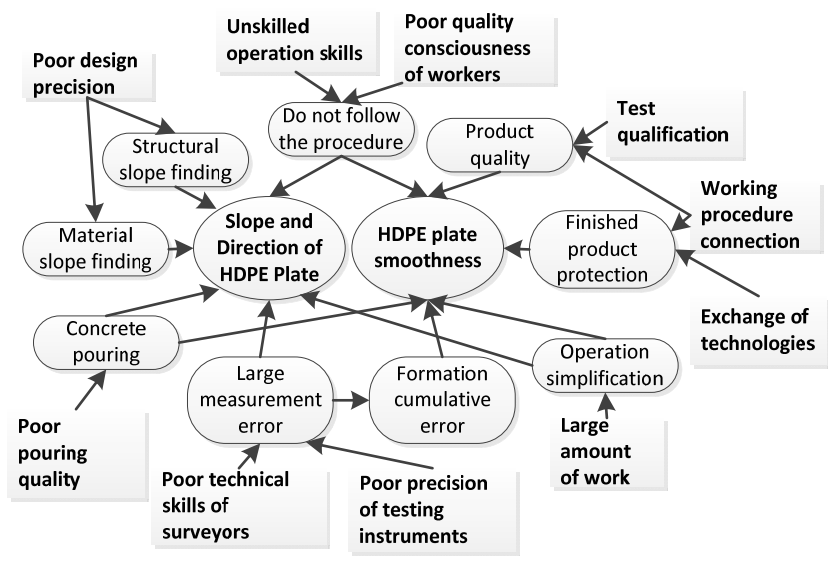

Fig. 2. Causality analysis diagram of quality

According to the causality diagram, the causes of the 9 end factors are investigated and demonstrated on the spot. It is determined that "poor quality of technical interaction, low design precision and large control error of concrete pouring elevation are the three main reasons that affect the quality of waterproof and drainage of garage planting roof.

\section{Quality Control based on PDCA}

\subsection{Planning (P)}

According to the field investigation and the above chart analysis, the current qualified rate is 86.7, and the cumulative frequency of defects in board slope and direction of HDPE and HDPE smoothness is 75. If the quality problems of these two items can be completely eliminated, the qualified rate can reach $96.7 \%$, but taking into account some unforeseen factors, the target qualified rate is determined to be $96 \%$.

Aiming at the three main reasons that shown above, the following plans are made:

- The head of supervision shall make a technical record of the workers, send special personnel to supervise them, and carry out the technical examination of the workers.

- Combination of finer structural slope finding and material slope searching;carrying on the zoning design.

- The elevation control rod shall be provided, and the elevation control shall be within the specification permitted by the specification.

\subsection{Plans to implement (D)}

\subsubsection{Technical interaction}

The project manager shall organize the relevant departments to review the drawings before the construction of the project, understand the construction drawings of buildings and structures, and understand the technical requirements of the key positions and special parts of the waterproofing and drainage construction of the planting roof. At the same time, the project engineer carries on the written technical exchange to the technical personnel. Technicians should fully understand and master the design intent, structural characteristics and technical requirements of the design, and explain and answer questions about the contents of the exchange. And according to the characteristics of the technical structure of the project, all the personnel in the field were explained and technical training was carried out.

\subsubsection{Roof concrete elevation control}

One of the main reasons for the leakage of underground garage roof is the large error in controlling the elevation of roof concrete. Based on the characteristics of large area of underground garage and many districts, the accuracy of structural slope finding can be strengthened by improving the elevation accuracy of the whole project, and the final precise docking of each district can be ensured. The construction process should be carried out in strict accordance with the technological process ${ }^{[4]}$.

The key points of control are formwork elevation control, slope elevation control and concrete pouring elevation control.

\subsubsection{Increase the smoothness and slope of HDPE drains}

In the course of laying drainage board, special attention should be paid to the laying of drainage plates and geotextile. And the construction process should be in accordance with the technological process to ensure the quality ${ }^{[5]}$.

For example, the convex point of the drainage plate should face to the surface of the water, which naturally unfolds and is laid vertically or horizontally according to the gradient of the drainage. A small number of bricks can be used to fix the drainage plates in view of the uneven lap. When temporary fixation is needed, glue is used to fix. Protective measures should be taken for the sewer that has been laid. When laying geotextile, a layer of supporting net can be laid above the drainage plates to form an integral hollow layer with the drainage plates. If suture is used, special care should be taken at the suture site to ensure that no gravel in the soil or gravel coating enters the middle of the geotextile. 


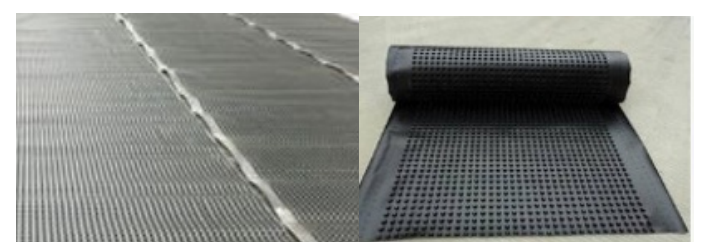

Fig. 3. Laying of HDPE drainage board.

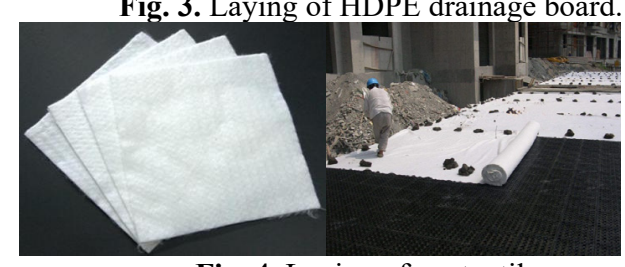

Fig. 4. Laying of geotextile.

\subsection{Effect check (C)}

In the process of construction, it is found that the quality awareness and technical ability of the workers have been obviously improved. At the same time, through the combination of the above methods, according to the real-time detection records, all the data are within the allowable range of the measurement error. Through the sampling inspection of 250 completed planting roof's waterproof and drainage construction points, the one-off qualified rate of self-inspection has been raised to 96, which shows that the plan goal is achieved.

Table 2. Quality inspection statistics

\begin{tabular}{|c|c|c|c|c|c|c|c|}
\hline & Project & Numbers & Qualified & $\begin{array}{c}\text { Qualified } \\
\text { rate }\end{array}$ & unqualified & $\begin{array}{c}\text { unqualified } \\
\text { rate }\end{array}$ & $\begin{array}{l}\text { Cumulative } \\
\text { frequency }\end{array}$ \\
\hline 1 & $\begin{array}{l}\text { Slope and direction } \\
\text { of HDPE plates }\end{array}$ & 50 & 49 & \multirow{6}{*}{$96 \%$} & 1 & $10 \%$ & $10 \%$ \\
\hline 2 & HDPE plates smoothness & 50 & 47 & & 3 & $30 \%$ & $40 \%$ \\
\hline 3 & Non-woven fabric suture firm & 50 & 48 & & 2 & $20 \%$ & $60 \%$ \\
\hline 4 & Non-woven fabric smoothness & 50 & 48 & & 2 & $20 \%$ & $80 \%$ \\
\hline \multirow[t]{2}{*}{5} & HDPE lap & 50 & 48 & & 2 & $20 \%$ & $100 \%$ \\
\hline & Total & 250 & 240 & & 10 & $100 \%$ & \\
\hline
\end{tabular}

\subsection{Consolidation measures (A)}

\subsubsection{Construction standardization}

In order to better grasp the results of this QC control, we should sum up on this basis, compile the relevant quality control key points, instructions and other documents, and release the application in the enterprise. At the same time, the corresponding measures should be incorporated into the internal management system of the project, and technical training or quality education should be organized regularly by the project master to promote standardization of the construction process.

\subsubsection{Refinement of the construction process}

In the process of construction, the HDPE plates should be accepted in different parts. The side station should be supervised during the operation. And the operator should be explained in detail. After each part, each procedure construction is completed, the supervision unit and the construction unit are requested to carry on the spot acceptance and the test to the spot quality.

\section{Conclusion}

Through the PDCA quality cycle management, the waterproofing and drainage system of underground garage's planted roof of A project in Q City has been perfected. No leakage has occurred so far. Good economic and social benefits have been achieved.

\section{References}

1. D.Z. Zhang, Architectural Waterproofing (China City Press, 2014)

2. C.L. Shen, L. Li Design and Construction Technology of planting Roof (China Building Materials Industry Press, 2016)

3. D.Z. Zhang, G.Y. Chen, Discussion on the design and application of storage and drainage layer for planting Roof. Waterproofing of Chinese buildings. J. 11, 5-7 (2015)

4. Ministry of Urban-Rural Construction of the people's Republic of China, GB 50164-2011 concrete quality Control Standard (China Construction Industry Press, 2011)

5. China Construction Waterproofing Association, JGJ 155-2013 Technical Specification for Roof planting (China Construction Industry Press, 2013) 